\title{
USE OF Cavia porcellus (GUINEA PIGS) AS AN EXPERIMENTAL MODEL FOR
}

Leishmania (Viannia) braziliensis

\section{PAULA C. D. R. (1), FRIEDMAN H. (1), SAMPAIO R. N. R. (1)}

(1) School of Medicine, University of Brasília, UnB, Brasília, Distrito Federal, Brazil.

ABSTRACT: Laboratory animals are fundamental to study immunological aspects and the efficacy of new drugs to treat leishmaniasis. However, we do not have practical and good animal models to study leishmaniasis caused by Leishmania (Viannia) braziliensis - $L(V) b$. In this study, thirty-two experimental animals (Cavia porcellus) were injected in the hind foot with $3 \times 10^{5}$ promastigote forms of $L(V) b$. The animals were followed for eight weeks. None of the experimental animals developed lesions or presented the parasite in any of the tests performed (histopathological exam, smears, culture, inoculation in hamsters, and polymerase chain reaction).

KEY WORDS: experimental leishmaniasis, Cavia, animal model, American leishmaniasis, pathogenesis.

\section{CORRESPONDENCE TO:}

CARMEM DÉA RIBEIRO DE PAULA, Laboratório de Dermatomicologia, Faculdade de Medicina, Universidade de Brasília, Campus Universitário, Brasília, DF, Brasil. Phone/Fax: 5561 3285047. Email: cwpaula@uol.com.br. 


\section{INTRODUCTION}

American tegumentary leishmaniasis (ATL) is in frank expansion in Brazil and all over the world (8). The biological cycle of leishmaniasis involves the sandfly, the reservoirs, and the final host $(16,17)$. The vectors and the reservoirs are difficult to control, since they are generally wild and some may not be known yet.

Leishmania (Viannia) braziliensis - $L(V) b$ - is an important etiologic agent in Brazil due to its high morbidity, principally by the compromising of mucous membranes, which, in some cases, leads to deformations of the facial region and death $(10,13)$.

The usual control measure for ATL is treatment of the infected individual. New drugs have been discovered to act against leishmaniasis, and laboratory animals are fundamental to study the efficacy of these drugs.

So far, we do not have practical and good animal models to study leishmaniasis caused by $L(V) b$. However, previous studies on the inoculation of Leishmania (Viannia) braziliensis and Leishmania (Leishmania) guyanensis in Cavia porcellus showed promising results $(11,15)$.

In this study, our objective was to verify the susceptibility of Cavia porcellus to infection by $L(V) b$.

\section{METHODS}

This was an experimental study carried out in a laboratory. Thirty-two experimental animals were injected in the hind foot with $3 \times 10^{5}$ promastigote forms of $L(V) b$, strain MHOM/BR/94/M15176, identified by monoclonal antibodies and polymerase chain reaction (PCR). The animals were followed for eight weeks. Weekly, two individuals were sacrificed and fragments of their foot, liver, spleen, regional ganglia, nose, and bone marrow were taken for parasitological tests $(4,5,14)$ : culture, smears, inoculation in hamsters, polymerase chain reaction (2), and histopathological exam $(3,9)$.

\section{RESULTS}

There was no development of skin lesions. All the methods used for $L(V) b$ detection smears, culture, histopathological exam, inoculation in hamsters, and PCR - showed negative results. No cellular infiltration was observed in the histopathological exam. 


\section{DISCUSSION}

Susceptibility of cavy to $L(L)$ enrietti has already been documented by a number of authors $(7,11,12)$. The infection caused by $L(V) b$ was demonstrated by SCORZA et al. in 1992 (15). Despite the results shown by this author, the search for mucous metastasis was negative using various laboratory methods, including PCR. Current works studying the genome of $L(V) b$ have shown variability within the species (6). Such differences have also been reported and could explain discordant results that were found in this study.

Although we used a dose of promastigotes similar to that of other authors, and even three times higher than that used by SCORZA et al., this inoculum has still been considered low. It has been reported that inoculums similar to those found in natural infection may cause asymptomatic infection, showing $\mathrm{T}$ lymphocyte cell answer equal to that observed in humans. Paradoxically, the possibility of transmission of leishmania to its vector is higher in lower doses (under $10^{6}$ promastigotes) that cause asymptomatic infection. It seems that this natural selection might be ideal for a longstanding life cycle of the parasite (1).

\section{CONCLUSION}

Cavia porcellus was not susceptible to inoculation with $3 \times 10^{5}$ promastigote forms of $L(V) b$ since none of the experimental animals developed lesions or showed presence of the parasite in any of the methods used. The alterations observed in the histopathological exam did not suggest the presence of leishmaniasis. More studies must be carried out to verify the susceptibility of Cavia porcellus to infection by $L(V) b$ with different doses of promastigotes. Besides, the animals should be observed for at least six months, according to the protocol established by FUNASA.

\section{REFERENCES}

1 BRASIL. Ministério da Saúde. Fundação Nacional da Saúde (FUNASA). Manual de controle da leishmaniose tegumentar americana. 5. ed. rev. Brasília, 2000. $62 \mathrm{p}$.

2 CERQUEIRA EJL., SHERLOCK I., GUSMÃO A., BARBOSA Jr AA., NAKATANI M. Inoculação experimental de Equus asinus com Leishmania chagasi Cunha \& Chagas, 1937. Rev. Soc. Bras. Med. Trop., 2003, 36, 695-701. 
3 CUBA CUBA CA., MARSDEN PD., BARRETO AC., ROCHA R., SAMPAIO RR., PATZLAFF L. Parasitologic and immunologic diagnosis of American (mucocutaneous) leishmaniasis. Bull. Pan Am. Health Organ., 1981, 15, 24959.

4 CUBA CUBA CA., NETTO EM., MARSDEN PD., ROSA ADE C., LLANOSCUENTAS EA., COSTA JL. Cultivation of Leishmania braziliensis from skin ulcers in man under field conditions. Trans. R. Soc. Trop. Med. Hyg., 1986, 80, 456-7.

5 DE ALMEIDA MC., VILHENA V., BARRAL A., BARRAL-NETTO M. Leishmanial infection: analysis of its first steps. A review. Mem. Inst. Oswaldo Cruz, 2003, 98, 861-70.

6 DE BRUJIN MH., BARKER DC. Diagnosis of New World leishmaniasis: specific detection of species of the Leishmania braziliensis complex by amplification of kinetoplast DNA. Acta Trop., 1992, 52, 45-58.

7 FALQUETO A., SESSA PA., FERREIRA AL., VIEIRA VP., SANTOS CB., VAREJÃO JBM., CUPOLILlO E., PORROZZI R., CARVALHO-PAES LE., GRIMALDI Jr. G. Epidemiological clinical features of Leishmania (Viannia) braziliensis American cutaneous and mucocutaneous leishmaniasis in the State of Espírito Santo, Brazil. Mem. Inst. Oswaldo Cruz, 2003, 98, 1003-10.

8 KANAN MW. Mucocutaneous leishmaniasis in guinea pigs inoculated intravenously with Leishmania enriettii. Preliminary report. Br. J. Dermatol., 1975, 92, 66373.

9 MAGALHÃES AV., MORAES MAP., RAICK AN., LLANOS-CUENTAS A., COSTA JML., CUBA CC., MARSDEN PD. Histopatologia da leishmaniose tegumentar por Leishmania braziliensis braziliensis. Classificação histopatológica. Rev. Inst. Med. Trop. São Paulo, 1986, 28, 253-62.

10 MARSDEN PD. Mucosal leishmaniasis ("espundia" Escomel, 1911). Trans. R. Soc. Trop. Med. Hyg., 1986, 80, 859-76.

11 MEDINA H. Estudos sobre leishmaniose: I. Primeiros casos de leishmaniose espontânea observados em cobáios. Braz. Arch. Biol. Technol., 2001, v. jubilee, 13-55.

12 PARAENSE WL. Infection of the nasal mucosa in guinea pig leishmaniasis. An. Acad. Bras. Ciênc., 1952, 24, 307-10. 
13 PESSOA SB., BARRETO MP. Epidemiologia . In: PESSOA SB., BARRETO MP. Eds. Leishmaniose tegumentar americana. Rio de Janeiro: Ministério da Educação e Saúde, 1948: 35-64.

14 ROMERO GAS., LESSA HA., ORGE MG., MACEDO VO., MARSDEN PD. Tratamento da leishmaniose mucosa com sulfato de aminosidine: resultado e dois anos de acompanhamento. Rev. Soc. Bras. Med. Trop., 1998, 31, 511-6.

15 SCORZA JV., OVIEDO M., LOBO H., MÁRQUEZ JC. Leishmania braziliensis ssp in the nasal mucosa of guinea pigs inoculated in the tarsi. Mem. Inst. Oswaldo Cruz, 1992, 87, 81-6.

16 STRANGWAYS-DIXON J., LAINSON R. Dermal Leishmaniasis in British Honduras: transmission of L. braziliensis by Phlebotomus species. Br. Med. J., 1962, 3, 297-9.

17 STRANGWAYS-DIXON J., LAINSON R. The epidemiology of dermal leishmaniasis in British Honduras. Part III. The transmission of Leishmania mexicana to man by Phlebotomus pessoanus, with observations on the development of the parasite in different species of Phlebotomus. Trans. $R$. Soc. Trop. Med. Hyg., 1966, 60,192-207. 